\title{
Effect of ovulation on serum cholesterol in women of reproductive age group
}

\author{
Madhuri Panigrahi ${ }^{1}$, Santosh K. Panda ${ }^{2 *}$
}

\author{
${ }^{1}$ Department of Physiology, AIIMS, Bhubaneswar, Odisha, India \\ ${ }^{2}$ Department of Radiodiagnosis, P. R. M. Medical College, Baripada, Odisha, India
}

Received: 24 December 2017

Accepted: 05 January 2018

\section{*Correspondence:}

Dr. Santosh K. Panda,

E-mail: santosh160@gmail.com

Copyright: () the author(s), publisher and licensee Medip Academy. This is an open-access article distributed under the terms of the Creative Commons Attribution Non-Commercial License, which permits unrestricted non-commercial use, distribution, and reproduction in any medium, provided the original work is properly cited.

\section{ABSTRACT}

Background: Reproduction and contraception is mostly central around ovulation. The sex hormones undergo changes in levels with ovulation. They also play an important role in cholesterol metabolism, especially oestrogen. Aim of our study was to find out changes in serum cholesterol before and after ovulation in women of reproductive age.

Methods: In present study 70 women of reproductive age group (15-49years) were recruited. Serum cholesterol was measured around time of ovulation.

Results: It was found that, during the follicular phase there was a significant increase in total cholesterol and LDL-C concentrations compared to post ovulatory phase. During the ovulatory phase there was a decrease in total cholesterol and increase in HDL-C compared to follicular phase. VLDL levels showed increasing trend from follicular to post ovulatory phase.

Conclusions: Ovulation improves cardiovascular risk factors which may account of the decreased risk of cardiovascular diseases among ovulating women. And secondly, the menstrual cycle phase should be taken into account when evaluating cholesterol levels among reproductive age group women.

Keywords: Cholesterol, LDL, HDL, Ovulation, VLDL

\section{INTRODUCTION}

In reproductive age group women menstrual cycle and ovulation are important normal occurring events. It is well known that ovulation is the most important phenomenon around which the methods of reproduction and contraception revolve. ${ }^{1}$ Ovulation occurs around mid part of a normal regular menstrual cycle. With ovulation there occur changes in sex hormones in regularly menstruating women. ${ }^{2}$

The relation between sex hormones and cholesterol and consequently cardiovascular diseases has been studied over a long period by several investigators. ${ }^{3}$ Anovulation is associated with increased cardiovascular risk. ${ }^{4}$ So, it can be proposed that in regularly menstruating women, ovulation must have some protective effect on risk factors of cardiovascular diseases.

We know that Coronary heart disease (CHD) is the most prevalent manifestation of disease resulting in nearly $50 \%$ of all cardiovascular death in the world. Out of the risk factors for $\mathrm{CHD}$, serum cholesterol is the main cause of pathogenesis of this disease. ${ }^{5}$ In addition to total amount of cholesterol, the type of cholesterol (LDL, HDL, etc) is also important. ${ }^{6}$

Men have higher level of TG and LDL-C associated with higher risk of $\mathrm{CHD}$, whereas women have higher level of HDL-C associated with protection from CHD. ${ }^{7}$ This 
variation in lipid profile may be due to gender difference in sex hormones. Oestrogen appeared to affect serum cholesterol in that HDL-C is raised and LDL-C is lowered. ${ }^{8}$ In this present study we tried to find out the ways in which changes in serum cholesterol occurs around ovulation.

\section{METHODS}

The study was conducted in the Department of Physiology, Biochemistry and Radio diagnosis, SCB Medical College. Study was carried out from January 2014 to April 2016. It was a prospective analytical study.

70 women of reproductive age group (15-49years) were recruited in the study from the community. Routine physical examination and anthropometric measurement was done. Subjects were studied for 2 months.

In first month the menstrual cycle length and basal body temp (BBT) was determined. In $2^{\text {nd }}$ month- the determination of ovulation (By Ovulation kit) and Ultrasonography.

Trans-vaginal Ultrasonography was done in married women and trans-abdominal in case of unmarried ladies. Features of ovulation in USG are non-visualisation of previously visible dominant follicle and mild fluid in pelvis. Fasting blood sample were collected before and after ovulation i.e. in follicular and ovulatory phases.

\section{Inclusion and exclusion criteria}

Women having regular menstruation for three months were taken into study group and those taking any OCP or any hypolipidemic drugs for last 6 months were not selected into study.

\section{Serum cholesterol analysis}

It includes Total cholesterol (TC), High density lipoprotein cholesterol (HDL-C), Low density lipoprotein cholesterol (LDL-C) and very low density lipoprotein (VLDL).

Determination of serum cholesterol was performed using automated enzymatic methodology with Dimension Xpand Plus Analyser.

\section{Statistical analysis}

The obtained data were analyzed by using a software statistical package for the social science (SPSS version 20). Frequency and descriptive analyses were used to describe the data.

Paired samples t-test was also used to differentiate between two numerical data of two phases. Any difference or correlation was considered significant if $\mathrm{p}$ value less than 0.05 .

\section{RESULTS}

In present study 70 women of reproductive age were taken as subjects.

Table 1: Anthropometric data.

\begin{tabular}{|ll|} 
Category & Mean \pm SD \\
\hline Age $($ Year $)$ & $27.62 \pm 4.4$ \\
\hline Weight $(\mathrm{Kg})$ & $52.62 \pm 5.9$ \\
\hline Height $(\mathrm{mt})$ & $1.57 \pm .25$ \\
BMI $\left(\mathrm{Kg} / \mathrm{M}^{2}\right)$ & $22.05 \pm 2.7$ \\
\hline
\end{tabular}

They had mean age $27.62 \mathrm{yr}$, mean weight $52.62 \mathrm{~kg}$, mean height 1.57 meters and BMI $22.05 \mathrm{~kg} / \mathrm{m} 2$ (Table 1 , 2).

Table 2: BMI of study subjects.

\begin{tabular}{|lll|}
\hline Category & Number & Percentage \\
\hline Underweight & 2 & 2.86 \\
\hline Normal & 50 & 71.43 \\
\hline Overweight & 18 & 25.71 \\
\hline
\end{tabular}

Most of the subjects (around 71\%) are in normal range (18.5-24.9). ${ }^{9}$

Table 3: Total cholesterol value in follicular and ovulatory phase of study subjects.

\begin{tabular}{|lcc|}
\hline TC & Mean $(\mathrm{mg} / \mathrm{dl})$ & SD \\
\hline TC-F & 163.568 & 35.63 \\
\hline TC-O & 137.938 & 34.74 \\
\hline$\%$ Decreased after ovulation $=(163.568-137.938) /$ \\
$163.568=15.67 \%$
\end{tabular}

The mean total cholesterol value during follicular and ovulatory phase was 163.57 and $137.94 \mathrm{mg} / \mathrm{dl}$ respectively. So total cholesterol value has decreased by $15.6 \%$ in post-ovulation phase as compared to preovulation phase (Table 3,7 ).

Table 4: HDL value of follicular and ovulatory phase of study subjects.

\begin{tabular}{|lcc|}
\hline HDL & Mean & SD \\
\hline HDL-F & 44.562 & 9.34 \\
\hline HDL-O & 67.592 & 18.72 \\
\hline $\begin{array}{l}\text { Increase } \\
\text { 51.68\% }\end{array}$ & & \\
\hline
\end{tabular}

The mean HDL value during follicular and ovulatory phase was 44.56 and $67.59 \mathrm{mg} / \mathrm{dl}$ respectively. Hence HDL increased by $51.68 \%$ after ovulation as compared to pre-ovulation (Table 4, 7).

The mean LDL value during follicular and ovulatory phase was 96.84 and $81.54 \mathrm{mg} / \mathrm{dl}$ respectively. So, LDL 
cholesterol decreased by $15.79 \%$ after ovulation as compared to pre-ovulation phase (Table 5, 7).

Table 5: HDL value of follicular and ovulatory phase of study subjects.

\begin{tabular}{|lcc|}
\hline LDL & Mean $(\mathrm{mg} / \mathrm{dll})$ & SD \\
\hline LDL-F & 96.84 & 22.46 \\
\hline LDL-O & 81.54 & 20.42 \\
\hline $\begin{array}{l}\text { \% Decrease after ovulation }=(96.84 \\
=15.79 \%\end{array}$ & \\
\hline
\end{tabular}

The mean VLDL value during follicular and ovulatory phase was 25.98, $27.02 \mathrm{mg} / \mathrm{dl}$ respectively. VLDL value increased by $4 \%$ after ovulation (Table 6,7 ).

Table 6: VLDL during follicular and ovulatory phase.

\begin{tabular}{|lcc|}
\hline VLDL & Mean & SD \\
\hline VLDL-F & 25.98 & 7.1 \\
\hline VLDL-O & 27.02 & 7.6 \\
\hline \% Increase & after & ovulation $=(27.02-25.98) / 25.98=4 \%$ \\
\hline
\end{tabular}

HDL showed highest variation $(51.68 \%)$ in its level after ovulation as compared to pre-ovulatory phase (Table 7).

Table 7: \% variation of cholesterol after ovulation.

\begin{tabular}{|ll|}
\hline Type of cholesterol & \% variation after ovulation \\
\hline TC & -15.67 \\
\hline HDL & +51.68 \\
\hline LDL & -15.79 \\
\hline VLDL & +4 \\
\hline
\end{tabular}

TC/HDL ratio was found to be 3.67 and 2.04 in follicular and ovulatory phase respectively. The ratio had decreased significantly in ovulatory phase as compared to follicular phase (Table 8).

Table 8: Ratio of TC to HDL.

\begin{tabular}{|lll|}
\hline Ratio & Mean & SD \\
\hline TC-F/HDL-F & 3.67 & 0.70 \\
\hline TC-O/HDL-O & 2.04 & 0.71 \\
\hline
\end{tabular}

\section{DISCUSSION}

Most of the study subjects were within normal range of BMI (Table 1 and 2). ${ }^{9}$

Change in serum cholesterol after ovulation is described as below.

\section{Total Cholesterol (TC)}

The total cholesterol value has decreased by $15.6 \%$ in ovulatory phase as compared to follicular phase (Table 3 ). The reduction in total plasma cholesterol during post ovulatory phase of the cycle occurred when progesterone levels were expected to peak and estrogen was on the average higher levels. ${ }^{10}$

This is in agreement with the results of other investigators as follows, Hemer et al, Kim et al, Mattsson et al, Schijf et al, Tikkanen et al, Sunni M et al, Sharma $\mathrm{BD}$ et al, and Gupta $\mathrm{K}$ et al. ${ }^{11-18}$

\section{High density lipoprotein cholesterol (HDL-C)}

In the present study it was found that HDL increased by $51.68 \%$ in ovulatory phase as compared to follicular phase (Table 4). The significant elevation in HDL-C concentrations during the ovulatory phase could be due to expected increased levels of estrogen during ovulatory phase as compared to follicular phase. ${ }^{10}$

Similar to present study, Saxena AR et al found that in the post ovulatory phase, levels of estrogen, progesterone, luteinizing hormone, total cholesterol and HDL were significantly higher, compared with the follicular phase. ${ }^{19}$

Contrary to above it was reported by Kim et al that an increase in HDL-C levels was observed during the luteal phase of the cycle but this difference was not significant when compared with the follicular and ovulatory phases. $^{12}$

Studies conducted by de Mendoza et al, Kim et al, Demacker et al, Hemer et al, Lebech et al, Schijf et al, Woods et al, Jones et al, reported no significant changes in HDL-C concentrations after ovulation. ${ }^{12,14,20-25}$

\section{Low density lipoprotein cholesterol (LDL-C)}

The value of LDL cholesterol decreased by $15.79 \%$ in ovulatory phase as compared to follicular phase (Table 5). The reduction in plasma LDL-C levels may be because progesterone level was expected to peak and estrogen was on average higher level (de Mendoza et al). ${ }^{20}$

It may be due to the increased suppression in the activity of the Hepatic lipase (HL) enzyme (Tikkanen et al), which is induced by the concentrations of estrogen secretion. Another possible mechanism for the reduction in LDL-C levels may be as a result of increase in hepatic LDL receptor. ${ }^{26}$

In addition, estrogen administration causes an increase in the catabolism of LDL by increasing hepatic LDL receptor activity. Since the major site for the uptake of LDL occurs primarily in the liver, and the rise in estrogen secretion enhances the uptake process, it may be suggested that the effects of estrogen are manifested through HL activity and consequently on hepatic degradation of LDL levels.

Present study findings are comparable with the study conducted by Mumford et al. ${ }^{16}$ 
The following studies differ from present study

- The Gorbach et al observed a significant decrease in LDL-C levels during the follicular phase. ${ }^{27}$

- Barclay et al observed insignificant variations in plasma LDL-C levels before and after ovulation. ${ }^{10}$

- de Mendoza et al found that LDL-C values were not significantly different during the follicular and the post ovulatory phases, in agreement with Demacker et al. ${ }^{20,21}$

- Lebech et al, Woods et al, reported no significant variations in the concentrations of LDL-C after ovulation. $^{23,24}$

\section{Very low density lipoprotein (VLDL)}

In this present study VLDL value increased by $4 \%$ in ovulatory phase as compared to follicular phase (Table 6).

Similar results were observed by Gupta K et al. Oestrogen increases the light subtype of VLDL that decreases the artherogenicity leading to overall beneficial effects. ${ }^{18}$

\section{Ratio of total cholesterol with high density lipoprotein (TC/HDL)}

TC/HDL ratio was found to be 3.67 and 2.04 in follicular and ovulatory phase respectively. The ratio had decreased significantly in ovulatory phase as compared to follicular phase in our study (Table 8).

Gupta $\mathrm{K}$ et al and Devi $\mathrm{K}$ et al demonstrated that TC/HDL ratio declined significantly in post ovulatory phase as compared to follicular phase. ${ }^{18,28}$ This may be due to increase of HDL levels, decrease TC levels in ovulatory phase as compared to follicular phase which is due to increase estrogen and progesterone levels.

Oestrogen exerts a favourable effect on cholesterol metabolism by various mechanisms like l9,30 $^{29}$

- Increasing VLDL-C synthesis leading to subsequent decrease in LDL-C and increase in HDL-C

- Up regulate the LDL receptors.

- Up regulate ATP Binding Cassette Transporter-A1 (ABCA1) and Apolipoprotein-A1 (APOA1, a most important HDL protein, which enhance HDL production).

- $\quad$ Suppress hepatic scavenger receptor Class B Type 1 (SR-BI) activity leading to reduced hepatic cholesterol uptake.

\section{CONCLUSION}

- During the follicular phase of the normal menstrual cycle there was a significant increase in total cholesterol and LDL-C concentrations compared to post ovulatory phase.

- During the ovulatory phase of menstrual cycle there was increase in HDL-C compared to follicular phase.

- VLDL levels show increasing trend from follicular to post ovulatory phase.

So, it can be concluded that ovulation improves cardiovascular risk factors which may account of the decreased risk of cardiovascular diseases among ovulating women. And secondly, the menstrual cycle phase should be taken into account when evaluating cholesterol levels among reproductive-aged women.

Funding: No funding sources

Conflict of interest: None declared

Ethical approval: Not required

\section{REFERENCES}

1. Rivera R, Yacobson I, Grimes D. The mechanism of action of hormonal contraceptives and intrauterine contraceptive devices. Am J Obstet Gynecol. 1999 Nov;181(5 Pt 1):1263-9.

2. Reed BG, Carr BR. The normal menstrual cycle and the control of ovulation. Endotext [Internet]. South Dartmouth (MA): MDText.com, Inc.; 2000.

3. Briel M, Ferreira-Gonzalez I, You JJ, Karanicolas PJ, Akl EA, Wu P et al. Association between change in high density lipoprotein cholesterol and cardiovascular disease morbidity and mortality: systematic review and meta-regression analysis. BMJ. 2009 Feb 16;338:b92.

4. Legro RS. Polycystic ovary syndrome and cardiovascular disease: a premature association? Endocrine Rev. 2003 Jun 1;24(3):302-12.

5. Linton MF, Yancey PG, Davies SS, Jerome WG, Linton EF, Vickers KC. The role of lipids and lipoproteins in atherosclerosis. Endotext [Internet]. 2015.

6. Li X, Wang A, Wang J, Wu J, Wang D, Gao X, Wu S, Zhao X. Association between High-densitylipoprotein-cholesterol Levels and the Prevalence of Asymptomatic Intracranial Arterial Stenosis. Scientific Reports. 2017;7.

7. Freedman DS, Jacobsen SJ, Barboriak JJ, Sobocinski KA, Anderson AJ, Kissebah $\mathrm{AH}$ et al. Body fat distribution and male/female differences in lipids and lipoproteins. Circulation. 1990 May;81(5):1498-506.

8. Margolis CF, Sprecher DL, Simbartl LA, Campaigne BN. Male-female differences in the relationship between obesity and lipids/lipoproteins. Int J Obes Relat Metab Disord. 1996 Aug;20(8):784-90.

9. Park K. Park's textbook of social and preventive medicine. $23^{\text {rd }}$ ed. Bhanot;2015.

10. Barclay M, Barclay RK, Skipski VP, Terebus-Kekish $\mathrm{O}$, Mueller $\mathrm{CH}$, Shah E, Elkins WL. Fluctuations in human serum lipoproteins during the normal menstrual cycle. Biochem J. 1965;96(1):205. 
11. Hemer HA, DeBourges V, Ayalajjbrito G, GarzaFlores J. Variation in serum lipids and lipoproteins throughout the menstrual. Fertil Steril. 1985;44:80-4.

12. Kim HJ, Kalkhoff RK. Changes in lipoprotein composition during the menstrual cycle. Metabolism. 1979 Jun 1;28(6):663-8.

13. Mattsson LA, Silfverstolpe G, Samsioe G. Lipid composition of serum lipoproteins in relation to gonadal hormones during the normal menstrual cycle. Eur J Obstet Gynecol Reprod Biol. 1984 Jul;17(5):327-35.

14. Schijf CP, van der Mooren MJ, Doesburg WH, Thomas CM, Rolland R. Differences in serum lipids, lipoproteins, sex hormone binding globulin and testosterone between the follicular and the luteal phase of the menstrual cycle. Acta Endocrinologica. 1993 Aug 1;129(2):130-3.

15. Tikkanen MJ, Nikkila EA, Kuusi T, Sipinen S. Reduction of plasma high-density lipoprotein 2 cholesterol and increase of postheparin plasma hepatic lipase activity during progestin treatment. Clinica Chimica Acta. 1981 Aug 27;115(1):63-71.

16. Mumford SL, Dasharathy S, Pollack AZ. Variations in lipid levels according to menstrual cycle phase: clinical implications. Clini Lipidol. 2011;6(2):22534.

17. Pahwa MB, Seth S, Seth RK. Lipid profile in various phases of menstrual cycle and its relationship with percentage plasma volume changes. Clinica chimica acta. 1998 May 25;273(2):201-7.

18. Gupta K, Mathur K, Sankhla M. Influence of menstrual cycle phases on serum level of lipids and lipoprotein ratios in eumenorrheic women. Sch J App Med Sci. 2015;3:1769-72.

19. Saxena AR, Seely EW, Goldfine AB. Cardiovascular risk factors and menstrual cycle phase in premenopausal women. $\mathbf{J}$ Endocrinol Invest. 2012;35(8):715-9.

20. DeMendoza SG, Nucete H, Slazer E, Zerpa A, Kashyap ML. Plasma lipids and lipoprotein hyperactivator activity during the menstrual cycle. Hormone Metab Res. 1979;11:696-7.
21. Demacker PN, Schade RW, Stalenhoef AF, Stuyt PM, Van't Laar A. Influence of contraceptive pill and menstrual cycle on serum lipids and high-density lipoprotein cholesterol concentrations. $\mathrm{Br}$ Med $\mathrm{J}$ (Clin Res Ed). 1982 Apr 24;284(6324):1213-5.

22. Hemer HA, de Bourges VV, Ayala JJ, Brito G, DíazSánchez V, Garza-Flores J. Variations in serum lipids and lipoproteins throughout the menstrual cycle. Fertility and sterility. 1985 Jul 31;44(1):80-4.

23. Lebech AM, Kjaer A. Lipid metabolism and coagulation during the normal menstrual cycle. Hormone Metab Res. 1989 Aug;21(08):445-8.

24. Woods M, Schaefer EJ, Morrill A, Goldin BR, Longcope C, Dwyer JD et al. Effect of menstrual cycle phase on plasma lipids. J Clin Endocrinol Metab. 1987 Aug;65(2):321-3.

25. Jones DY, Judd JT, Taylor PR, Campbell WS, Nair PP. Menstrual cycle effect on plasma lipids. Metabolism. 1988 Jan;37(1):1-2.

26. Tikkanen MJ, Nikkila EA. Regulation of hepatic lipase and serum lipoproteins by sex steroids. Am Heart J. 1987;113:562-7.

27. Gorbach SL, Schaefer EJ, Woods M, Longcope C, Dwyer JT, Goldin BR, Morrill-LaBrode A, Dallal G. Plasma lipoprotein cholesterol and endogenous sex hormones in healthy young women. Metabolism. 1989 Nov;38(11):1077-81.

28. Devi K, Malleshappa K, Jeyalakshmi L. Association of acylation stimulating protein with endogenous sex hormones and lipid profile during menstrual cycle; Indian J Physiol Pharmacol. 2012;56(2):147-53.

29. Samsioe G. Cardioprotection by estrogens: mechanisms of action--the lipids. Int $\mathrm{J}$ Fertil Menopausal Stud. 1994;39:43-9.

30. Knopp RH, Zhu X. Multiple beneficial effects of estrogen on lipoprotein metabolism. J Clin Endocrinol Metab. 1997 Dec;82(12):3952-4.

Cite this article as: Panigrahi M, Panda SK. Effect of ovulation on serum cholesterol in women of reproductive age group. Int J Reprod Contracept Obstet Gynecol 2018;7:424-8. 